\title{
The Importance of a Borrower's Track Record on Repayment Performance: Evidence in P2P Lending Market
}

\author{
Dongwoo KIM ${ }^{1}$
}

Received: April 01, 2020 Revised: April 14, 2020 Accepted: July 05, 2020

\begin{abstract}
In peer-to-peer (P2P) loan markets, as most lenders are unskilled and inexperienced ordinary individuals, it is important to know the characteristics of borrowers that significantly impact their repayment performance. This study investigates the effects and importance of borrowers' past repayment performance track record within the platform to identify its predictive power. To this end, I analyze the detailed loan repayment data from two leading P2P lending platforms in Korea using a Cox proportional hazard, multiple linear regression, and logit models. Furthermore, the predictive power of the factors proxied by borrowers' track records are evaluated through the receiver operating characteristic (ROC) curves. As a result, it is found that the borrowers' past track record within the platform have the most important impact on the repayment performance of their current loans. In addition, this study also reveals that the borrowers' track record is much more predictive of their repayment performance than any other factor. The findings of this study emphasize that individual lenders must take into account the quality of borrowers' past transaction history when making a funding decision, and that platform operators should actively share the borrowers' past records within the markets with lenders.
\end{abstract}

Keywords : P2P Lending; South Korea; Track Records; Default Prediction

JEL Classification Code : C35, C53, D81, G41

\section{Introduction}

The biggest concern for lenders in the loan market is whether a borrower will be able to repay his/her loan properly. This is particularly of interest, in the P2P loan market, where ordinary individuals with insufficient credit evaluation experience serve as lenders. (Kim, 2020). P2P loans are rapidly growing worldwide, drawing attention to the possibility of alternative financing for traditional finance. However, the recent rise in loan defaults in major markets such as China and South Korea has been stoking the possibilities of sustainable growth. Finding factors affecting loan repayment results is an important concern as the P2P

${ }^{1}$ KB Financial Group, Korea [Postal Address: 26, Gukjegeumyung-ro 8-gil, Yeongdeungpo-gu, Seoul, 07331, Korea]

Email: dwkim0302@gmail.com

(c) Copyright: The Author(s)

This is an Open Access article distributed under the terms of the Creative Commons Attribution Non-Commercial License (http://Creativecommons.org/licenses/by-nc/4.0/) which permits unrestricted noncommercial use, distribution, and reproduction in any medium, provided the original work is properly cited. loan has a less systematic credit evaluation system and lacks experience compared to traditional finance. Thus, despite its relatively recent emergence, borrower's characteristic elements, and their relationship to repayment performance in the P2P loan market, is the subject of active academic research. Some of these studies focus on the specific characteristic elements of the borrower, including race (Pope \& Sydnor, 2011), gender (D. Chen, Li, \& Lai, 2017; X. Chen, Huang, \& Ye, 2020), perceived trustworthiness (Duarte, Siegel, \& Young, 2012), social networks (Everett, 2015; Freedman \& Jin, 2017; Lin, Prabhala, \& Viswanathan, 2013), university reputation (J. Li \& Hu, 2019), and communication with lenders (Xu \& Chau, 2018). Pope and Sydnor (2011) reported that black people are less successful than white people in loan repayment, using data from the U.S. Prosper platform. D. Chen et al. (2017) and X. Chen et al. (2020) used data from China's PPDAI and Renrendai platforms to argue that the default rates of female borrowers are significantly lower than those of male borrowers. Duarte et al. (2012) revealed that among Prosper's borrowers, those who seem to have high trustworthiness in their appearance actually have a low rate of insolvency. Everett (2015) argued that borrowers acting as members of a group show superior 
repayment performance than borrowers acting as individuals within the platform, and Freedman and Jin (2017) and Lin et al. (2013) claimed that people with good social relationships are better at paying back their loans. In addition, J. Li and $\mathrm{Hu}$ (2019) investigated college students who borrowed money from Renrendai in China and revealed that a borrower attending a university with a good reputation is likely to pay back better. $\mathrm{Xu}$ and Chau (2018) argued that the amount of communication between a borrower and lenders within a platform has nothing to do with the borrower's repayment performance. Furthermore, several studies have presented models to predict repayment performance using the relationship between a borrower's characteristic elements and his/her repayment performance $(\mathrm{Z}$. Li, Li, Yao, \& Wen, 2019; Tao, Dong, \& Lin, 2017; Wang, Zhang, Zhao, \& Wang, 2019). The main findings of the existing studies are listed in Table 1.

This study investigates the effects and importance of borrowers' past repayment performance records within the platform. More than 10 years have passed since the advent of P2P loans worldwide, and an increasing number of borrowers are accumulating a track record within the platform. Therefore, it is necessary to study whether these borrowers' past practices on the platform can be an important predictor of their creditworthiness. In this respect, this study contributes to the literature. Furthermore, most of the previous studies used a dichotomous variable with levels of success or failure as a dependent variable. The others adopted more granular levels of the dependent variable, but this also was a categorical variable. However, prior studies have limitations in that even loans classified as failure will inevitably differ in their performance depending on the degree of repayment. To overcome these limitations, this study analyzes not only the above binary variables but also the continuous variable: the repayment rate. It also attempts to increase the generalization of results by analyzing them in various ways, such as linear regression, logit, and survival analysis.

\section{Data and Methodology}

For this study, loan repayment data from Korea's P2P lending platform Moneyauction and Popfunding were extracted through a web scaping method as of December

Table 1: Summary of prior related research

\begin{tabular}{|c|c|c|c|}
\hline Literature & Platform & Method & Findings \\
\hline Chen et al. (2017) & Ppdai & $\begin{array}{l}\text { Cox proportional } \\
\text { hazard }\end{array}$ & $\begin{array}{l}\text { Loan default rates of female borrowers are lower than } \\
\text { those of male borrowers. }\end{array}$ \\
\hline Chen et al. (2020) & Renrendai & Logit & Female borrowers show lower probability of default. \\
\hline Duarte et al. (2012) & Prosper & $\begin{array}{l}\text { Cox proportional } \\
\text { hazard }\end{array}$ & $\begin{array}{l}\text { Borrowers who appear more trustworthy have higher } \\
\text { credit scores and show lower default rates. }\end{array}$ \\
\hline Everett (2015) & Prosper & Probit & $\begin{array}{l}\text { Borrowers who are members of a group that has } \\
\text { personal relationships have significantly lower loan } \\
\text { default rate. }\end{array}$ \\
\hline $\begin{array}{l}\text { Freedman and Jin } \\
(2017)\end{array}$ & Prosper & Probit & $\begin{array}{l}\text { Borrowers with social ties are more likely to pay late or } \\
\text { default. }\end{array}$ \\
\hline Li and Hu (2019) & Renrendai & $\begin{array}{l}\text { Probit } \\
\text { Logit } \\
\text { Heckman two-stage }\end{array}$ & $\begin{array}{l}\text { Borrowers who graduated from top ranking universities } \\
\text { have a lower possibility of loan default and a lower ratio } \\
\text { of loan default. }\end{array}$ \\
\hline Li et al. (2019) & LendingClub & Mitinomial logit & $\begin{array}{l}\text { Both prepayment and default can be accurately } \\
\text { predicted by a range of variables. }\end{array}$ \\
\hline Lin et al. (2013) & Prosper & $\begin{array}{l}\text { Cox proportional } \\
\text { hazard }\end{array}$ & Friendships lower ex post default rates. \\
\hline $\begin{array}{l}\text { Pope and Sydnor } \\
\text { (2011) }\end{array}$ & Prosper & $\begin{array}{l}\text { Cox proportional } \\
\text { hazard }\end{array}$ & Blacks have higher relative default rates than whites. \\
\hline Tao et al. (2017) & Renrendai & Probit & $\begin{array}{l}\text { Borrowers who earn higher incomes or own cars have } \\
\text { lower default probabilities. }\end{array}$ \\
\hline Wang et al. (2019) & Renrendai & Logit & Soft factors can predict the loan default probability. \\
\hline Xu and Chau (2018) & LendingMarket & $\begin{array}{l}\text { Cox proportional } \\
\text { hazard }\end{array}$ & $\begin{array}{l}\text { The amount of lender borrower communication cannot } \\
\text { predict the borrower's loan performance. }\end{array}$ \\
\hline
\end{tabular}


2017 and January 2020, respectively. The loan repayment data includes information about the actual amount of repayment along with the final loan repayment result and the actual payment period of the entire maturity month. In the case of Moneyauction, 4,390 records were analyzed, except for incomplete or missing data, of which 27 were repaid as they did not mature as of the collection date. In Popfunding, 60 out of the 2011 records with completeness were still in progress for repayment as of the collection date. Data showing a borrower's past track record in the platform include the number of successful or failed repayments in Moneyauction and the indicator of quality of repayment with four levels (i.e., A through D) and the number of normal monthly repayments in Popfunding. For each platform, the above two components were used as explanatory variables to represent the borrower's past track record, and the remaining information such as the loan amount, interest rate and maturity, gender, and age were used as control variables. The detailed description and brief statistics of the variables are provided in Tables 2 and 3, respectively.

The analytical methods included 1) a Cox proportional hazard survival analysis with a dependent variable of the repayment status (i.e., repayment success or failure) over monthly time, 2) a multiple linear regression analysis with a dependent variable of the repayment rate, a continuous variable representing the actual repayment amount relative to the final expected repayment amount; and 3) a logit analysis with a dependent variable of the final dichotomous repayment result (i.e., repayment success or failure). The Cox proportional hazard survival analysis was based on 4,390 and 2011 cases for each platform. The loans that were successfully repaid or in progress were treated as censored cases and the other loans of which the repayment failed were treated as uncensored. The multiple linear regression and logit analyses covered 4,363 and 1951 records for each platform, excluding records in progress of repayment. The following simple analytical models were employed in this study:

$$
W(t \mid x)=W_{0}(t) \exp (x \beta)
$$

where $W(t \mid x)$, as defined in the Cox's proportional hazard model (Cox, 1972), measures the loan default function at time $\mathrm{t}$ given that the loan survives until time $t . W_{0}(t)$ denotes a baseline default function, and $x$ is the vector of predictors. In this study, the exponent of the coefficient $\boldsymbol{\beta}$ is reported, which is the ratio of the expected default rate for each predictor and the baseline default rate. The default ratio, $\exp (\boldsymbol{\beta})$, for each predictor $x i$ indicates the multiples of the default probability relative to the baseline case.

$$
Y i=\alpha_{0}+\Sigma \beta i X i+\Sigma \gamma i C i+\varepsilon i
$$

$$
\operatorname{Prob}(Z i)=\alpha_{0}+\Sigma \boldsymbol{\beta} i X i+\Sigma \gamma i C i+\varepsilon i
$$

where $Y_{i}$ denotes the ratio of a borrower's actual amount of repayment to the expected amount on a cumulative basis in the linear regression model, $Z_{i}$ indicates the repayment status of loan $i . Z_{\mathrm{i}}$ equals 1 if the borrower has fully repaid the loan and 0 otherwise in the logit model. For each model, $X_{i}$ represents the explanatory variable and proxies the track records in this study. $C_{i}$ is a control variable representing loan amount, loan interest rate, loan duration, a borrower's gender and age, and other factors.

The Cox proportional hazard survival, linear regression, and logit models for the data from Moneyauction are models 1,2 , and 3 , and each model that analyzes Popfunding data is 4,5 , and 6 .

Furthermore, in order to investigate the predictive power of the track record variables, the predictive powers of the logit models for which the track record variable is or is not, respectively, were compared through the ROC curves. For each comparison, through random sampling, $80 \%$ of the data was used to construct predictive models, and the remaining $20 \%$ was tested for prediction. For the Moneyauction data, Model 3 with the track record variables and Model $3 \mathrm{~A}$ without them were compared, and for the Popfunding data, Model 6 and Model 6A were compared similarly. All analyses were conducted using the statistical package R (version 3.6.3).

\section{Results and Discussion}

First, on Moneyauction, as shown in model 1, the hazard ratios of the SUCCESS and FAILURE variables are 0.768 and 3.228 at $99 \%$ confidence levels, respectively. This means that as the number of prior repayment successes increases, the default probability of the current loan decreases; and, vice versa, the default probability of the current loan increases as the number of prior repayment failures increases. In addition, FAILURE's hazard ratio is high, indicating that it has a particularly significant impact on loan repayment performance. The FAILURE is shown to have the greatest impact on the time of default among all variables, and SUCCESS also has a major impact following the PURPOSE and INSURANCE variables. Models 2 and 3 also show that the SUCCESS and FAILURE variables have statistically significant relationships with the repayment rate and repayment status, respectively, at a 99\% confidence level. In particular, the relative weight analyses reveal that the effects of the SUCCESS and FAILURE variables on the dependent variables are more important than those of other variables, as the sum of the relative importance of the two variables is high at $36.571 \%$ in Model 2 and $42.720 \%$ in Model 3. In both models, the FAILURE is the most important variable, and the SUCCESS is less important than the DURATION, but is similar or higher to the RATE and 
Table 2: Variables

\begin{tabular}{|c|c|c|}
\hline \multicolumn{2}{|c|}{ Variables } & \multirow{2}{*}{ Explanations } \\
\hline Full name & Abbreviation & \\
\hline \multicolumn{3}{|l|}{ Dependent variables } \\
\hline Time & TIME & $\begin{array}{l}\text { - Period after execution to last monthly repayment. } \\
\text { - Is calculate after standardizing maturity to } 100 \text { for all loans, as the loan maturity } \\
\text { varies from } 2 \text { months to } 36 \text { months for each loan. }\end{array}$ \\
\hline Survival & SURVIVAL & $\begin{array}{l}\text { - Status of a loan in reference time }(1=\text { censored, if the repayment ended at that } \\
\text { time and defaulted, } 0=\text { uncensored, if repayment has been maintained or if } \\
\text { repayment has been made normally by maturity). }\end{array}$ \\
\hline Repayment status & STATUS & - Final loan results for matured loans ( 1 = repaid, 0 = default). \\
\hline Repaid ratio & RATIO & $\begin{array}{l}\text { - The ratio of an actual repaid amount to the total amount expected to be } \\
\text { redeemed for matured loans. }\end{array}$ \\
\hline \multicolumn{3}{|l|}{ Explanatory variables } \\
\hline $\begin{array}{l}\text { Number of past } \\
\text { repayment successes }\end{array}$ & SUCCESS & $\begin{array}{l}\text { - The number of past loans taken out by the borrower on the platform and } \\
\text { completed the repayment normally. }\end{array}$ \\
\hline $\begin{array}{l}\text { Number of past } \\
\text { repayment failures }\end{array}$ & FAILURE & $\begin{array}{l}\text { - The number of past loans taken out by the borrower on the platform that have } \\
\text { not been able to complete the repayment even though it has matured. }\end{array}$ \\
\hline $\begin{array}{l}\text { Number of past } \\
\text { ordinary repayments }\end{array}$ & ORDINARY & $\begin{array}{l}\text { - The total amount of months the borrower has paid back normally for the entire } \\
\text { loan he received on that platform in the past. }\end{array}$ \\
\hline $\begin{array}{l}\text { Quality of past } \\
\text { repayment results }\end{array}$ & QUALITY & $\begin{array}{l}\text { - The quality grade of a borrower's loan repayment performance assessed by the } \\
\text { platform operator based on the borrower's past history of overdue loans }(4=A \text {, } \\
3=B, 2=C, 1=D) \text {. }\end{array}$ \\
\hline \multicolumn{3}{|l|}{ Control variables } \\
\hline Amount & AMOUNT & - Loan execution amount \\
\hline Interest rate & RATE & - Loan interest rate in percentages \\
\hline Duration & DURATION & - Period after execution to maturity in months \\
\hline Number of investors & INVESTOR & - Number of investors who participated in the bidding. \\
\hline Purpose & PURPOSE & - The reason for applying for a borrower loan ( 1 = loan repayment, 0 = others). \\
\hline Length of text & TEXT & $\begin{array}{l}\text { - The number of characters of textual representations that describe why the } \\
\text { borrower applies for the loan or plans to repay it in the future. }\end{array}$ \\
\hline External credit grade & GRADE & $\begin{array}{l}\text { - Credit grades rated by third-party external credit rating agencies such as KCB } \\
\text { and NICE, for each borrower, ranging between 1, the highest, and 10, the } \\
\text { lowest (Han, Kang, \& Shin, 2016; Park \& Yoo, 2019). }\end{array}$ \\
\hline Internal credit score & SCORE & $\begin{array}{l}\text { - The credit score of a borrower determined by the platform operator, ranging } \\
\text { from } 0 \text { to } 600 \text { points. }\end{array}$ \\
\hline $\begin{array}{l}\text { Verification of home } \\
\text { number }\end{array}$ & HOME & $\begin{array}{l}\text { - Whether the platform operator has verified the authenticity of the borrower's } \\
\text { home phone number ( } 1=\text { verified, } 0=\text { unverified }) \text {. }\end{array}$ \\
\hline $\begin{array}{l}\text { Verification of office } \\
\text { number }\end{array}$ & OFFICE & $\begin{array}{l}\text { - Whether the platform operator has verified the authenticity of the borrower's } \\
\text { office phone number ( } 1=\text { verified, } 0=\text { unverified }) \text {. }\end{array}$ \\
\hline Income & INCOME & - A borrower's annual income of KRW10,000. \\
\hline Length of work & WORK & - A borrower's total working year. \\
\hline Public insurance & INSURANCE & $\begin{array}{l}\text { - Whether the borrower has four major public insurance policies }(1=\text { has, } 0=\text { do } \\
\text { not have). }\end{array}$ \\
\hline Gender & GENDER & - A borrower's sex (1 = man, 0 = woman). \\
\hline Age & $A G E$ & - The age of a borrower at the time of the loan application. \\
\hline Marriage & MARRIAGE & $\begin{array}{l}\text { - Whether the borrower was married at the time of the loan application ( } 1= \\
\text { married, } 0=\text { not married). }\end{array}$ \\
\hline Type of residence & RESIDENCE & - The form of residence of a borrower ( $1=$ owned, $0=$ rent). \\
\hline
\end{tabular}


Table 3: Descriptive statistics

\begin{tabular}{|c|c|c|c|c|c|c|}
\hline \multirow{2}{*}{ Variables } & \multicolumn{3}{|c|}{ Moneyauction } & \multicolumn{3}{|c|}{ Popfunding } \\
\hline & $\mathbf{N}$ & Mean & S.E. & $\mathbf{N}$ & Mean & S.E. \\
\hline \multicolumn{7}{|l|}{ Dependent variables } \\
\hline TIME & 4390 & 82.189 & 0.461 & 2011 & 88.338 & 0.553 \\
\hline SURVIVAL & 4390 & 0.339 & 0.007 & 2011 & 0.206 & 0.009 \\
\hline - Censored (=1) & 1489 & & & 415 & & \\
\hline - Uncensored $(=0)$ & 2901 & & & 1596 & & \\
\hline STATUS & 4390 & 0.655 & 0.007 & 2011 & 0.761 & 0.010 \\
\hline - Repaid (=1) & 2874 & & & 1531 & & \\
\hline - Default (=0) & 1516 & & & 480 & & \\
\hline RATIO & 4390 & 0.852 & 0.004 & 2011 & 0.859 & 0.006 \\
\hline \multicolumn{7}{|l|}{ Explanatory variables } \\
\hline SUCCESS & 4390 & 0.421 & 0.014 & & & \\
\hline FAILURE & 4390 & 0.026 & 0.003 & & & \\
\hline ORDINARY & & & & 2011 & 38.332 & 0.714 \\
\hline QUALITY & & & & 2011 & 2.884 & 0.024 \\
\hline \multicolumn{7}{|l|}{ Control variables } \\
\hline AMOUNT & 4390 & 506.603 & 8.555 & 2011 & 223.396 & 2.900 \\
\hline RATE & 4390 & 30.333 & 0.084 & 2011 & 28.653 & 0.056 \\
\hline DURATION & 4390 & 20.118 & 0.102 & 2011 & 14.054 & 0.130 \\
\hline INVESTOR & 4390 & 39.409 & 0.373 & 2011 & 116.683 & 1.251 \\
\hline PUPOSE & 4390 & 0.311 & 0.007 & & & \\
\hline - Loan repayment (=1) & 1367 & & & & & \\
\hline - Others $(=0)$ & 3023 & & & & & \\
\hline TEXT & 4390 & 620.076 & 7.759 & 2011 & 1334.254 & 21.073 \\
\hline GRADE & 4390 & 7.090 & 0.023 & & & \\
\hline SCORE & 4390 & 250.229 & 1.142 & & & \\
\hline HOME & & & & 2011 & 0.373 & 0.011 \\
\hline - Verified (=1) & & & & 751 & & \\
\hline - Unverified (=0) & & & & 1260 & & \\
\hline OFFICE & & & & 2011 & 0.682 & 0.010 \\
\hline - Verified (=1) & & & & 1371 & & \\
\hline - Unverified (=0) & & & & 640 & & \\
\hline INCOME & 4390 & 4186.365 & 70.020 & & & \\
\hline WORK & 4390 & 2.771 & 0.061 & & & \\
\hline INSURANCE & 4390 & 0.603 & 0.007 & & & \\
\hline$-\operatorname{Has}(=1)$ & 2646 & & & & & \\
\hline - Do not have $(=0)$ & 1744 & & & & & \\
\hline GENDER & 4390 & 0.672 & 0.007 & 2011 & 0.498 & 0.011 \\
\hline - Man (=1) & 2950 & & & 1001 & & \\
\hline - Woman (=0) & 1440 & & & 1010 & & \\
\hline$A G E$ & 4390 & 32.867 & 0.101 & 2011 & 43.575 & 0.132 \\
\hline MARRIAGE & 4390 & 0.388 & 0.007 & & & \\
\hline - Married (=1) & 1703 & & & & & \\
\hline - Not married $(=0)$ & 2687 & & & & & \\
\hline RESIDENCE & 4390 & 0.449 & 0.008 & & & \\
\hline - Owned (=1) & 1973 & & & & & \\
\hline - Rent (=0) & 2417 & & & & & \\
\hline
\end{tabular}


$G R A D E$ variables depending on the model. Consequently, the results of Models 1, 2, and 3 show that the borrower's past track record in the platform have greater impacts on loan repayment performance than other factors.

Next, for Popfunding, the hazard ratios for the ORDINARY and QUALITY variables are 0.950 and 0.388 , respectively, which are significant at the $99 \%$ confidence level. This indicates that the number of monthly ordinary repayments and the quality of past repayments of the borrower adversely affect the time of default for his/her current loan. In particular, the quality level of the borrower's past repayments would be very influential on the survival status of his/her current loan. Models 5 and 6 show that both variables affect the repayment rate and repayment status in a positive direction at a $99 \%$ confidence level. Moreover, the relative weight analyses report that the combined relative importance of the two variables is $91.582 \%$ for model 5 and $90.045 \%$ for model 6 , which has an absolute effect on the dependent variable compared to the other variables. The analysis results are aggregated in Table 4.

Figures 1 and 2 analyze the predictive power of the borrower's track record for his/her repayment performance in each platform. First, as seen in the ROC curve in Figure 1, for Moneyauction, the AUC (area under the curve) values of Model 3, which contains the SUCCESS and FAILURE variables and Model 3A, which exclude the explanatory variables, are reported as 0.661 and 0.724 , respectively. This means that the addition of the explanatory variables improves the predictive power of the model by approximately $10 \%$ compared to otherwise. Looking at the ROC curve in Figure 2, more dramatic results are shown in Popfunding. The AUC value (i.e., 0.897) of model 6

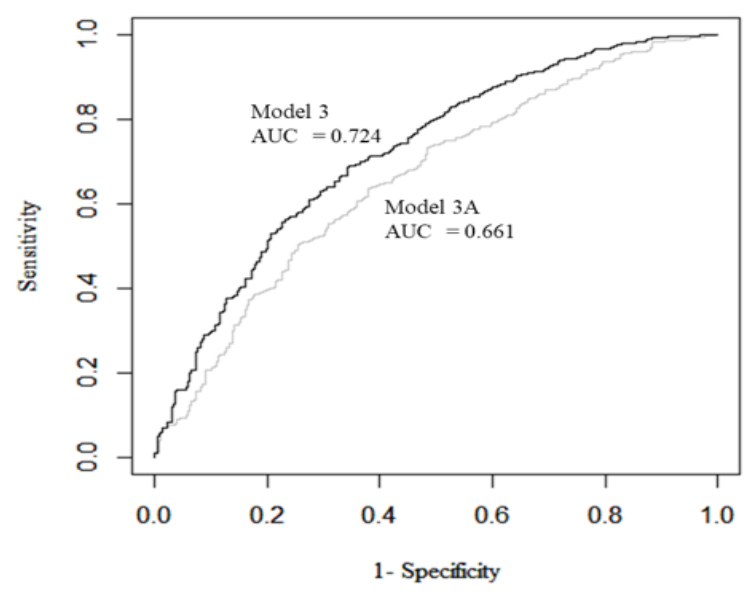

Figure 1: ROC curves for Models 3 and $3 \mathrm{~A}$ with the ORDINARY and QUALITY variables is shown to be significantly higher than that (i.e., 0.567) of model 6 A without the explanatory variables, indicating that the borrower's track repayment performance compared to other factors.

The study reveals that the borrower's past track record in the platform has the most impact on the repayment performance of his/her current loan in the Korean P2P lending market. This is in line with the results that Ding, Huang, and Meng (2019) analyzed using Renrendai platform data from China. The results of this study are rather surprising where it is assumed that the borrower's credit and loan information such as credit score, income level, loan amount, loan interest rate, and loan maturity are likely to have a significant impact on the borrower's record is highly predictive of his/her repayment performance.

In P2P loans, the platform operator provides a lot of information to help individual lenders evaluate a borrower's creditworthiness in making their funding decisions. While some of this information is taken from the borrower and passed on to the lenders, there are also internal borrower credit scores that the platform operator evaluates on its own. As such, the platform operator strives to support the lenders' judgments, but in fact, lenders have limited access to analytical information about what factors are actually important. Considering that most lenders who participate in P2P loan markets are unskilled and inexperienced individuals (Kim, 2020), there may be too much information that lenders need to refer to for their decision making. Such an excessive provision of information may hamper lenders' decision-making. Therefore, the platform operator needs to continue to provide lenders with the importance and quality of the borrower's information.

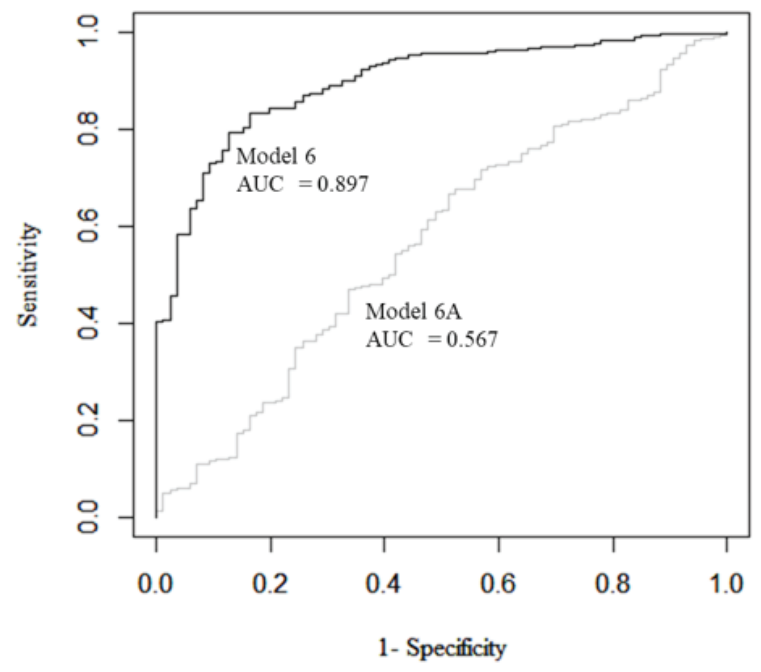

Figure 2: ROC curves for Models 6 and $6 \mathrm{~A}$ 
Table 4: Analyses of the effect of a borrower's track records on his/her repayment performance

\begin{tabular}{|c|c|c|c|c|c|c|c|c|c|c|}
\hline \multirow{3}{*}{ Variables } & \multicolumn{5}{|c|}{ Moneyauction } & \multicolumn{5}{|c|}{ Popfunding } \\
\hline & \multirow{2}{*}{$\begin{array}{c}\text { Model } 1 \\
\text { CoxPH.exp }(\beta)\end{array}$} & \multicolumn{2}{|c|}{ Model 2} & \multicolumn{2}{|c|}{ Model 3} & \multirow{2}{*}{\begin{tabular}{|c|} 
Model 4 \\
CoxPH.exp $(\beta)$ \\
\end{tabular}} & \multicolumn{2}{|c|}{ Model 5} & \multicolumn{2}{|c|}{ Model 6} \\
\hline & & LR. $\beta$ & LR.RW & Logit. $\beta$ & $\begin{array}{l}\text { Logit. } \\
\text { RW }\end{array}$ & & LR. $\beta$ & LR.RW & Logit. $\beta$ & $\begin{array}{l}\text { Logit. } \\
\text { RW }\end{array}$ \\
\hline SUCCESS & $0.768^{* *}$ & $0.030^{* *}$ & $9.750 *$ & $0.333^{* *}$ & $11.601^{*}$ & & & & & \\
\hline FAILURE & $3.228^{* *}$ & $-0.254^{* *}$ & $26.821^{* *}$ & $-2.874^{* *}$ & 30.119 * & & & & & \\
\hline ORDINARY & & & & & & 0.950 ** & $0.003^{* *}$ & $34.124^{* *}$ & $0.058^{* *}$ & $48.500^{* *}$ \\
\hline QUALITY & & & & & & $0.388^{* *}$ & $0.101^{* *}$ & $57.458^{* *}$ & $1.323^{* *}$ & $41.545^{* *}$ \\
\hline AMOUNT & $1.000002 e+00$ & $5.444 \mathrm{e}-06$ & 0.481 & $-3.303 e-05$ & 0.687 & $1.003^{* *}$ & $-2.881 \mathrm{e}-04^{* *}$ & $2.212^{* *}$ & $-0.006^{* *}$ & $3.780^{* *}$ \\
\hline RATE & $1.039^{* *}$ & $-0.003^{* *}$ & $6.967^{\star *}$ & $-0.045^{* *}$ & $11.312^{*}$ & $0.961^{*}$ & $0.009^{* *}$ & $1.291^{*}$ & $0.124^{* *}$ & $0.973^{*}$ \\
\hline DURATION & $1.042^{* *}$ & $-0.006^{* *}$ & $19.135^{* *}$ & $-0.053^{* *}$ & 15.306 * & $1.075^{* *}$ & -0.002 & $1.491^{*}$ & $-0.064^{* *}$ & $2.391^{* *}$ \\
\hline INVESTOR & $1.008^{* *}$ & $-0.001^{* *}$ & $4.083^{* *}$ & $-0.009^{* *}$ & $4.841^{\text {** }}$ & 0.999 & $8.367 e-06$ & 0.428 & 0.001 & $0.643^{*}$ \\
\hline \multicolumn{11}{|l|}{$\begin{array}{l}\text { PURPOSE: } \\
\text { Others }\end{array}$} \\
\hline $\begin{array}{l}\text { PURPOSE: } \\
\text { Loan } \\
\text { repayment }\end{array}$ & $0.680 *$ & $0.048^{* *}$ & $3.893^{* *}$ & $0.516^{* *}$ & 3.246 * & & & & & \\
\hline TEXT & $9.9996 \mathrm{e}-01$ & $5.280 \mathrm{e}-06$ & 0.219 & $4.017 \mathrm{e}-05$ & 0.277 & $9.999 \mathrm{e}-01^{*}$ & $7.166 \mathrm{e}-06$ & 0.166 & $1.683 e-04^{*}$ & 0.249 \\
\hline GRADE & $1.139^{* *}$ & $-0.017^{*}$ & $9.995^{* *}$ & $-0.161^{* *}$ & 10.554 * & & & & & \\
\hline SCORE & $1.00002 \mathrm{e}+00$ & $-8.054 e-05$ & 0.680 & $-2.619 e-04$ & $1.126^{*}$ & & & & & \\
\hline \multicolumn{11}{|l|}{$\begin{array}{l}\text { HOME: } \\
\text { Unverified }\end{array}$} \\
\hline HOME: Verified & & & & & & 1.203 & -0.004 & 0.308 & $-0.301^{*}$ & $1.100^{*}$ \\
\hline \multicolumn{11}{|l|}{$\begin{array}{l}\text { OFFICE: } \\
\text { Unverified }\end{array}$} \\
\hline $\begin{array}{l}\text { OFFICE: } \\
\text { Verified }\end{array}$ & & & & & & $0.757^{*}$ & $0.039^{* *}$ & 0.538 & $0.419^{*}$ & 0.219 \\
\hline INCOME & $9.9997 \mathrm{e}-01$ ** & $1.698 \mathrm{e}-06$ & 0.786 & $3.933 \mathrm{e}-05^{* *}$ & $3.792^{*}$ & & & & & \\
\hline WORK & $0.983^{*}$ & $0.003^{*}$ & $2.080^{*}$ & 0.018 & 1.476 & & & & & \\
\hline \multicolumn{11}{|l|}{$\begin{array}{l}\text { INSURANCE: } \\
\text { Do not have }\end{array}$} \\
\hline $\begin{array}{l}\text { INSURANCE: } \\
\text { Has }\end{array}$ & $0.757^{* *}$ & 0.050 & $7.080 *$ & $0.352^{* *}$ & 3.264 * & & & & & \\
\hline \multicolumn{11}{|l|}{$\begin{array}{l}\text { GENDER: } \\
\text { Woman }\end{array}$} \\
\hline GENDER: Man & $1.144^{*}$ & -0.015 & 0.690 & $-0.178^{*}$ & 0.644 & $1.244^{*}$ & $-0.036^{* *}$ & $1.124^{*}$ & -0.262 & 0.241 \\
\hline$A G E$ & 1.005 & $-0.002^{* *}$ & 1.014 & -0.005 & 0.247 & 0.997 & 0.001 & $0.860^{*}$ & -0.001 & 0.359 \\
\hline \multicolumn{11}{|l|}{$\begin{array}{l}\text { MARRIAGE: } \\
\text { Not married }\end{array}$} \\
\hline $\begin{array}{l}\text { MARRIAGE: } \\
\text { Married }\end{array}$ & 1.013 & 0.002 & 0.354 & -0.017 & 0.196 & & & & & \\
\hline \multicolumn{11}{|l|}{$\begin{array}{l}\text { RESIDENCE: } \\
\text { Rent }\end{array}$} \\
\hline $\begin{array}{l}\text { RESIDENCE: } \\
\text { Owned }\end{array}$ & $0.816^{* *}$ & $0.045^{* *}$ & $5.971 *$ & $0.233^{* *}$ & 1.312 & & & & & \\
\hline (Intercept) & & $1.207^{* *}$ & & $4.281^{* *}$ & & & $0.239^{* *}$ & & $-5.229^{* *}$ & \\
\hline$N$ & 4390 & 4363 & & 4363 & & 2011 & 1951 & & 195 & \\
\hline Model fit & $\begin{array}{c}\text { C-index }=0.675 \\
\text { Adjusted } R 2= \\
0.124 \\
\text { LR } X^{2}=581.2^{* *} \\
\text { Wald }=613.5^{* *} \\
\text { Logrank }= \\
676.1^{* *}\end{array}$ & Adjusted $R 2=$ & $=0.101$ & $\begin{array}{r}\text { C-index }= \\
\text { Pseudo } R 2 \\
L R X^{2}=5\end{array}$ & $\begin{array}{l}0.705 \\
=0.170 \\
2.75^{* *}\end{array}$ & $\begin{array}{c}\text { C-index }= \\
0.860 \\
\text { Adjusted } R 2= \\
0.341 \\
\text { LR } x^{2}=838.8^{* *} \\
\text { Wald }=564.4^{* *} \\
\text { Logrank }= \\
784.1^{* *}\end{array}$ & Adjusted R2 & $=0.279$ & $\begin{array}{r}\text { C-index }= \\
\text { Pseudo R2 } \\
\operatorname{LR}^{2}=8\end{array}$ & $\begin{array}{l}=0.904 \\
2=0.532 \\
23.61^{* *}\end{array}$ \\
\hline
\end{tabular}

Note: $\beta$ and RW represent the regression coefficient and relative weight, respectively.

** and ${ }^{*}$ indicate statistical significance at the $1 \%$ and $5 \%$ levels, respectively. 


\section{Conclusions}

This study investigates the effects and importance of borrowers' past repayment performance track record within the platform to identify its predictive power. To this end, I analyze the detailed loan repayment data from two leading P2P lending platforms in Korea using a Cox proportional hazard, multiple linear regression, and logit models. Furthermore, the predictive power of the factors proxied by borrowers' track records are evaluated through the receiver operating characteristic (ROC) curves. As a result, it is found that the borrowers' past track record within the platform have the most important impact on the repayment performance of their current loans. In addition, this study also reveals that the borrowers' track record is much more predictive of their repayment performance than any other factor.

The study provides theoretical contributions in that it reveals the importance of the borrower's past track record in P2P loan markets and, in particular, for the first time in Korea's multi-platform. Especially, it also contributes to existing studies in that it has not only found the relationship between the borrower's past track record and the loan repayment performance, but also identifies the relative importance of the past track record and how much it improves the predictive power over the borrower's repayment performance. Given that existing studies have limitations by using a dichotomous categorical variable indicating whether the repayment is successful or failed as a dependent variable, this study has the distinction of using a continuous variable of repayment rate, as well as the dichotomous category variable, in order to increase the accuracy of the analysis. It is also meaningful in that it first identifies the important role the borrower's past track record plays in his/her repayment performance and prediction.

From a practical perspective, the findings provide important implications for participants in P2P loan markets. First, the platform operator needs to periodically analyze empirical data and share with the lenders what factors of the borrower's information significantly impact performance in order to help lenders make decisions. In addition, lenders need to recognize that the factors that will be considered important in assessing a borrower's creditworthiness in P2P loans are somewhat different from those considered in assessing the borrower's creditworthiness in traditional finance. Borrowers should understand that they must manage their track record within the platform in order to continue to receive good funding from the lenders.

The study reveals that the borrower's past track record within the platform has important effects on their repayment performance. However, it is necessary for the borrower to first succeed in funding on the platform to have a past track record. In addition, most of them are first-time borrowers, rather than those who have had multiple experiences borrowing within the platform. Thus, although a borrower's past performance is important, it does not apply to borrowers with no prior experience. Therefore, the results of this study provide limited implications for assessing the ability of borrowers to repay loans for the first time on the platform. In this regard, further research on the differences in factors in the repayment outcome between the borrower who has no prior experience in P2P loan markets and the borrower who has extensive loan experience is likely to contribute to the existing study. In this study, the number of successful repayments and the number of failed repayments in the past are used as proxies of the borrower's past track records in each platform. However, even loans classified as successful repayment may have different details of repayment. In addition, loans classified as failure to repay is also likely to differ depending on the degree of repayment. Although this study did not reflect these differences due to the limitations of the data, it would be possible to draw more meaningful implications if these were supplemented in the future.

\section{References}

Chen, D., Li, X., \& Lai, F. (2017). Gender discrimination in online peer-to-peer credit lending: Evidence from a lending platform in China. Electronic Commerce Research, 17, 553-583.

Chen, X., Huang, B., \& Ye, D. (2020). Gender gap in peer-to-peer lending: Evidence from China. Journal of Banking \& Finance, 112, 105633.

Cox, D. R. (1972). Regression models and life-tables. Journal of the Royal Statistical Society: Series B (Methodological), 34(2), 187-202.

Ding, J., Huang, J., \& Meng, M. (2019). Is there an effective reputation mechanism in peer-to-peer lending? Evidence from China. Finance Research Letters, 30, 208-215.

Duarte, J., Siegel, S., \& Young, L. (2012). Trust and credit: The role of appearance in peer-to-peer lending. The Review of Financial Studies, 25(8), 2455-2484.

Everett, C. (2015). Group membership, relationship banking and loan default risk: The case of online social lending. Banking and Finance Review, 7(2), 15-54.

Freedman, S., \& Jin, G. Z. (2017). The information value of online social networks: Lessons from peer-to-peer lending. International Journal of Industrial Organization, 51, 185-222.

Han, S.-H., Kang, K., \& Shin, y. S. (2016). Bond rating, Corporate governance, and cost of debt: The case of Korea. Journal of Asian Finance, Economics and Business, 5(15), 5-15.

Kim, D. (2020). The importance of detailed patterns of herding behaviour in a P2P lending market. Applied Economics Letters, 27(2), 127-130. 
Li, J., \& Hu, J. (2019). Does university reputation matter? Evidence from peer-to-peer lending. Finance Research Letters, 31, 66-77.

Li, Z., Li, K., Yao, X., \& Wen, Q. (2019). Predicting prepayment and default risks of unsecured consumer loans in online lending. Emerging Markets Finance and Trade, 55(1), 118-132.

Lin, M., Prabhala, N. R., \& Viswanathan, S. (2013). Judging borrowers by the company they keep: Friendship networks and information asymmetry in online peer-to-peer lending. Management Science, 59(1), 17-35.

Park, H., \& Yoo, Y. (2019). Differences among credit rating agencies and the information envirionment. Journal of Asian Finance, Economics and Business, 6(2), 25-32.
Pope, D. G., \& Sydnor, J. R. (2011). What's in a picture? Evidence of discrimination from Prosper.com. Journal of Human Resources, 46(1), 53-92.

Tao, Q., Dong, Y., \& Lin, Z. (2017). Who can get money? Evidence from the Chinese peer-to-peer lending platform. Information Systems Frontiers, 19(3), 425-441.

Wang, C., Zhang, W., Zhao, X., \& Wang, J. (2019). Soft information in online peer-to-peer lending: Evidence from a leading platform in China. Electronic Commerce Research and Applications, 36, 100873.

Xu, J. J., \& Chau, M. (2018). Cheap talk? The impact of lenderborrower communication on peer-to-peer lending outcomes. Journal of Management Information Systems, 35(1), 53-85. 